\title{
Improved overall survival in dendritic cell vaccination-induced immunoreactive subgroup of advanced melanoma patients Ruggero Ridolfi*1, Massimiliano Petrini ${ }^{2}$, Laura Fiammenghi², Monica Stefanelli ${ }^{1}$, Laura Ridolfi ${ }^{1}$, Michela Ballardini ${ }^{2}$, Giuseppe Migliori ${ }^{3}$ and Angela Riccobon ${ }^{1}$
}

Address: ${ }^{1}$ Department of Medical Oncology, Morgagni-Pierantoni Hospital, Via Forlanini 34, 47100 Forlì, Italy, ${ }^{2}$ Istituto Oncologico Romagnolo, Via Forlanini 34, 47100 Forlì, Italy and ${ }^{3}$ Blood Transfusion Unit, Morgagni-Pierantoni Hospital, Via Forlanini 34, 47100 Forlì, Italy

Email: Ruggero Ridolfi* - r.ridolfi@ausl.fo.it; Massimiliano Petrini - m.petrini@ausl.fo.it; Laura Fiammenghi - l.fiammenghi@ausl.fo.it; Monica Stefanelli - m.stefanelli@ausl.fo.it; Laura Ridolfi - l.ridolfi@ausl.fo.it; Michela Ballardini - m.ballardini@ior-forli.it; Giuseppe Migliori - g.migliori@ausl.fo.it; Angela Riccobon - a.riccobon@ausl.fo.it

* Corresponding author

Published: 16 August 2006

Journal of Translational Medicine 2006, 4:36 doi:10.1 186/1479-5876-4-36
Received: 16 May 2006

Accepted: 16 August 2006

This article is available from: http://www.translational-medicine.com/content/4/I/36

(C) 2006 Ridolfi et al; licensee BioMed Central Ltd.

This is an Open Access article distributed under the terms of the Creative Commons Attribution License (http://creativecommons.org/licenses/by/2.0), which permits unrestricted use, distribution, and reproduction in any medium, provided the original work is properly cited.

\begin{abstract}
Background: We present our experience of therapeutic vaccination using dendritic cells (DC) pulsed with autologous tumor antigens in patients with advanced melanoma.

Methods: Twenty-one pretreated advanced melanoma patients were vaccinated with autologous DC pulsed with $100 \mu \mathrm{g} / \mathrm{ml}$ of autologous-tumor-lysate (ATL) or - homogenate (ATH) and $50 \mu \mathrm{g} /$ $\mathrm{ml}$ of keyhole limpet hemocyanin (KLH). The first 8 patients were treated subcutaneously or intradermally with immature-DC (iDC) (range $\left.4.5-82 \times 10^{6}\right)$ and the remaining 13 intradermally with in vitro matured $\mathrm{DC}(\mathrm{mDC})\left(\right.$ range $\left.1.2-26 \times 10^{6}\right)$. Subcutaneous interleukin-2 $\left(3 \times 10^{6} \mathrm{IU}\right)$ was administered from days 3 to 7 of each treatment cycle.
\end{abstract}

Results: Three of the 8 iDC patients obtained stabilizations (SD), each of 6 months' duration. The $13 \mathrm{mDC}$ patients showed I complete response ( 8 months), I partial response ( 3 months), 2 mixed responses ( 6 and 12 months) and 3 SD $(9,7+$, and $3+$ months). Overall responses (OR) were observed in $4 / 21$ (19\%) patients, or $4 / 13$ (30.7\%) considering mDC treatment only. 10/2I (47.6\%) patients showed non progressive disease (NPD), with 7/I3 (53.8\%) cases of NPD for mDC-treated patients. No major toxicities were observed. The positive delayed-type hypersensitivity (DTH) test to ATL/ATH and/or KLH correlated with increased overall survival (OS). Median OS was 24 months (range $3-45$ ) for the 10 DTH-positive (I iDC and $9 \mathrm{mDC}$ ) and 5 months (range 3-14) for the II DTH-negative patients $(\mathrm{P}<0.00 \mathrm{I})$. The in vitro evaluation of gamma IFN-secreting T-cells in 10 patients showed good correlation with both DTH (75\%) and clinical outcome $(70 \%)$.

Conclusion: Vaccination using DC pulsed with ATL/ATH and KLH in advanced melanoma patients is well tolerated and can induce a clinical response, especially when $\mathrm{mDC}$ are used. Successful immunization, verified by positive DTH, leads to longer survival. 


\section{Background}

In the complex interaction of relationships that exist between the immune system and cancer, therapeutic vaccination can be considered as a valid approach to overcoming the established state of immunotolerance between the two systems $[1,2]$.

The use of dendritic cells (DC) derived from peripheral blood precursors and pulsed with tumor antigens forms the basis of experimental and clinical trials on antitumor vaccinations $[3,4]$. Although numerous clinical studies have reported interesting objective regressions, case series are often small with limited overall response rates [5]. A recent review on antitumor vaccines, especially with regard to melanoma, attributed an overall response (OR) of $3.8 \%$, with an encouraging $7.1 \%$ for DC vaccines [6].

Although OR rates for vaccination are somewhat limited, results obtained with DC vaccinations can be considered promising, also because of the low toxicity observed [7]. The majority of these studies have aimed at demonstrating immunization against a single or a cocktail of well defined antigens and, considering the potentially enormous number of antigens presented by the tumor and remodelled over time $[8,9]$, it is rather surprising that any clinical responses have been observed at all [10-13]. However, in addition to the fundamental choice of antigens, the generation, cell culture, maturation status, and administration modalities of DC represent other critical steps needed for the good outcome of therapeutic vaccination.

At present, most authors use leukapheresis as source of DC [14-16]. Furthermore, the initial use of immature DC (iDC) has been replaced by that of DC matured in vitro (mDC) $[17,18]$. Conversely, the number of DC to administer, vaccination scheduling and duration, and routes of administration have still to be defined [19-21].

Another critical and much discussed issue is the clinical use of cytokines as vaccination adjuvants. In particular, it is not clear whether the administration of interkeukin-2 (IL-2) is necessary, useful, or counterproductive for clinical results [22-26].

It is also difficult to carry out a critical review of DC studies because the evaluation criteria used (WHO, RECIST) do not adapt well to some clinical situations obtained with vaccination $[27,28]$. The problem could, in part, be resolved by carrying out immunomonitoring, which is feasible for vaccinations with one or a small number of defined antigens, but much more complex when undefined antigen complexes are used [29].

We present an in-depth description of a phase I-II study of therapeutic vaccination using DC pulsed with autologous tumor lysate (ATL) or homogenate (ATH) and with keyhole limpet hemocyanin (KLH) in advanced melanoma patients. The study was begun in 2001 and was thus influenced by our own experience and by that of other authors.

\section{Methods Patients}

From August 2001 to September 2005, 21 patients with advanced melanoma were entered onto the vaccination protocol using autologous DC pulsed with ATL or ATH and KLH. Eight patients were treated with immature DC (iDC) and 13 with mature $\mathrm{DC}(\mathrm{mDC})$. Inclusion criteria were age $<70$ years, histologically confirmed diagnosis of melanoma, measurable disease (excluding brain metastases), previous removal of one or more metastatic lesions from which a sufficient quantity of ATL/ATH was obtained for at least 6 vaccinations, Performance Status $(P S) \leq 2$ (according to ECOG criteria), life expectancy more than 4 months.

\section{Treatment}

The first 8 patients were treated with iDC (range $4.5-82$ $\times 10^{6}$ ) via subcutaneous or intradermal injection with an insulin needle. Several inoculations were made (average 6-8) near the groin or the armpit in non metastatic, non lymphadenectomized sites. A further 13 patients were treated with intradermal mDC (range 1.2-26 × 106) alone following the abovementioned criteria, but with 8-10 inoculations. Subcutaneous IL-2 (Chiron, Milan, Italy) 3,000,000 IU/day was administered about 48 hours after each vaccination for 5 consecutive days. The first 4 vaccinations were carried out at intervals of 15 days and once a month thereafter.

Clinical evaluation (in partial acordance with RECIST criteria [28]), and delayed-type hypersensitivity (DTH) assessment were carried out before the first vaccination, after the 4 th vaccination, and every 2 vaccinations thereafter. The disappearance of, or an important reduction in pre-existing lesions in concomitance with disease progression in other sites, was considered as a mixed response (MR). If progression did not compromise the patient's general conditions, several more vaccinations were carried out until progression was irrefutably documented. The best response obtained was considered for evaluation purposes. Toxicity or adverse events were assessed after each vaccine administration.

The study protocol was reviewed and approved by the local Ethics Committee, in accordance with ethical standards laid down in the 1964 Declaration of Helsinki, and authorized in July 2001 by the Italian Ministry of Health. All patients gave their informed written consent to receive treatment. 


\section{Autologous Tumor Lysate (ATL) preparation}

Surgically removed tumor samples were mechanically dispersed to create a single-cell suspension. The largest pieces were incubated at $37^{\circ} \mathrm{C}$ in enzyme mix (collagenase $0.1 \%$, hyaluronidase $0.01 \%$, DNAse $0.1 \%$, Sigma, Milan, Italy) in RPMI 1640, (PAA Laboratories GmbH, Pasching, Austria) for 3 hours. At the end of incubation the pellets were washed 3 times with PBS and incubated for at least 20 minutes in sterile distilled water. Lysis was monitored by light microscope. Larger particles were removed by centrifugation ( $10 \mathrm{~min}$ at $600 \mathrm{~g}$ ) and the supernatant was passed through a $0.2-\mu \mathrm{m}$ filter. Protein contents were determined and aliquots were stored at $-80^{\circ} \mathrm{C}$ until use, after verification of sterility.

\section{Autologous Tumor Homogenate (ATH) preparation}

In some cases, the surgically removed tissue was stored at $-80^{\circ} \mathrm{C}$ because the decision to vaccinate had still not been taken. Frozen tissue fragments were pulverized in a dismembrator after immersion in liquid nitrogen. Pulverized tissue was then suspended in PBS. After centrifugation, the supernatant was treated as described above.

\section{DC generation}

DC were prepared from peripheral blood monocytes (PBMC) obtained by leukapheresis without previous mobilization. Five to nine liters of blood were processed in each collection. PBMC were purified on Ficoll-Paque. An aliquot of PBMC was utilized immediately for DC generation and the rest was frozen in bags for use at a later date (4-5 bags/each collection).

PBMC were incubated in tissue culture flasks with CellGro DC medium (Cell Genix, Freiburg, Germany) at $10 \times 10^{6}$ cells/ml for $2 \mathrm{~h}$. The non-adherent cells were discarded and the adherent cells were incubated in CellGro DC medium containing $1000 \mathrm{IU} / \mathrm{ml}$ rhIL-4 (Cell Genix, Freiburg, Germany) and $1000 \mathrm{IU} / \mathrm{ml}$ rhGM-CSF (Schering-Plough, Milan, Italy) for 7 days to generate a DCenriched cell population. On day $6,90 \%$ of the DC culture was pulsed with ATL/ATH $(100 \mathrm{mg} / \mathrm{ml})$, while the remaining $10 \%$ was pulsed with $\mathrm{KLH}(50 \mathrm{mg} / \mathrm{ml})$. Both cultures were then incubated overnight. On day 7 , the cells were defined as immature DC (iDC). After eliminating the previous culture medium, pulsed iDC were cultured for a further 2 days with a cocktail of cytokines (TNF $\alpha$, IL-1 $\beta$, IL-6, Endogen, Pierce Biotechnology, Rockford, USA; $\mathrm{PGE}_{2}$, Cayman Chemical, Ann Arbor, MI, USA). On day 9 they were defined as mature DC (mDC). iDC or $\mathrm{mDc}$ were removed, washed and suspended in sterile saline for therapeutic infusion into the patient (iDC, range $4.5-82 \times 10^{6} ; \mathrm{mDc}$, range $1.2-26 \times 10^{6}$ ).

\section{Phenotype analysis}

iDC and mDC phenotypes were determined by single or two-color fluorescence analysis in cells labelled with monoclonal antibodies (mAbs) and fixed in paraformaldehyde $2 \%$. The fluorescence was analyzed by a FACS Vantage flow cytometer (Becton Dickinson, Milan, Italy). mAbs specific for human CD1a, CD14, CD80, CD86, HLA-DR (Becton Dickinson), CD83 (Immunotech, Marseille, France) and CCR7 (BD Pharmingen, Milan, Italy) were used.

\section{In Vivo monitoring}

ATL or ATH $(10 \mu \mathrm{g})$ and KLH $(5 \mu \mathrm{g})$ were each suspended in $500 \mu \mathrm{l}$ of PBS and injected intradermally into the forearm of the patient. PBS alone was used as negative control.

\section{In Vitro immunomonitoring}

\section{Evaluation of interferon-gamma-secreting cells}

The patient's lymphocytes were collected and frozen before the first vaccination, after 4-6 vaccinations, and after 8-13 vaccinations. After thawing, $10 \times 10^{6}$ lymphocytes were stimulated in vitro overnight with ATL/ATH and $10 \times 10^{6}$ with KLH. Positive and negative controls were always included. Interferon-gamma (IFN- $\gamma$ ) secreting cells were detected using the IFN- $\gamma$ Secretion Assay Cell Enrichment and Detection Kit (Miltenyi Biotec, Bergisch Gladbach, Germany) according to the manufacturer's instructions.

\section{Statistical evaluations}

Survival time was calculated as the time between the date of the first cycle of therapy and the date of death from any cause. Survival curves were traced by the Kaplan-Meier method and the comparison between the two groups was based on the Log-Rank test. A two- sided P value of 5\% was considered as significant. All analyses were performed using the R statistical software package.

\section{Results}

Patient characteristics were as follows: 13 males, 8 females, with a median age of 52 years (range 35-75). Pretreatments, sites of evaluable disease, and PS are analytically described and analyzed in Table 1, together with the HLA determination of each patient. Two patients older than 70 years but in good general conditions were enrolled onto the study and treated on a compassionate basis.

The number of cells administered for each vaccination was about $10 \times 10^{6}$, with a higher median for iDC $(17 \times$ $10^{6}$, range: $\left.11-49.5\right)$ than for $\operatorname{mDC}\left(9.5 \times 10^{6}\right.$, range: $5.9-$ 12.6). A total of 145 administrations (49 iDC and 96 mDC) were made. 
Table I: Patient characteristics

\begin{tabular}{|c|c|c|c|c|c|c|}
\hline Patient ID & Sex & Age (Years) & PS (ECOG) & HLA & Site of Evaluable Disease & Pretreatments \\
\hline I L.A. & $M$ & 75 & 1 & $\mathrm{~A}_{2} \mathrm{~A}_{32} \mathrm{Cw}_{4} \mathrm{Cw}_{6}$ & spleen, soft tissue & IFN \\
\hline 2 G.I. & $\mathrm{F}$ & 66 & 0 & $\mathrm{~A}_{24} \mathrm{~A}_{11} \mathrm{~B}_{44} \mathrm{~B}_{18} \mathrm{Bw}_{4} \mathrm{Bw}_{6} \mathrm{Cw}_{5} \mathrm{Cw}_{7}$ & pelvis & $\mathrm{CT}+\mathrm{RT}$ \\
\hline 3 M.G. & $M$ & 73 & I & $A_{1} A_{10} B_{13} B_{41} B_{w_{4}} B_{w_{6}}$ & liver, lymph node & $\mathrm{CT}$ \\
\hline 4 S.P. & $M$ & 56 & I & $\mathrm{A}_{9} \mathrm{~A}_{32} \mathrm{~B}_{38} \mathrm{~B}_{55} \mathrm{Bw}_{4} \mathrm{Bw}_{6} \mathrm{Cw}_{3}$ & lung, bone, lymph node & BIOCT \\
\hline 5 G.C. & $M$ & 51 & 0 & $\mathrm{~A}_{1} \mathrm{~A}_{2} \mathrm{~B}_{8} \mathrm{~B}_{35} \mathrm{Bw}_{6} \mathrm{Cw}_{4} \mathrm{Cw}_{7}$ & liver, lymph node & IFN \\
\hline 6 Z.V. & $M$ & 42 & 1 & $A_{1} A_{19} B_{51} B_{14}$ & lung & BIOCT \\
\hline 7 G.L. & $M$ & 56 & 2 & $\mathrm{~A}_{3} \mathrm{~A}_{28} \mathrm{~B}_{35} \mathrm{~B}_{53} \mathrm{Cw}_{4}$ & liver & BIOCT \\
\hline 8 B.A. & M & 35 & 2 & $\mathrm{~A}_{2} \mathrm{~A}_{9} \mathrm{~B}_{7} \mathrm{~B}_{15} \mathrm{Bw}_{6} \mathrm{Cw}_{3} \mathrm{Cw}_{7}$ & lung, bone skin & BIOCT \\
\hline 9 P.M. & $M$ & 45 & 0 & $\mathrm{~A}_{1} \mathrm{~A}_{9} \mathrm{~B}_{17} \mathrm{Bw}_{4} \mathrm{Bw}_{6} \mathrm{Cw}_{3} \mathrm{Cw}_{4}$ & lung, lymph node & $\mathrm{BIO}, \mathrm{BIOCT}$ \\
\hline 10 P.M. & $M$ & 52 & 0 & $\mathrm{~A}_{11} \mathrm{~A}_{31} \mathrm{~B}_{14} \mathrm{~B}_{60} \mathrm{Bw}_{6} \mathrm{Cw}_{3}$ & kidney, adrenal gland & BIOCT \\
\hline I I R.L. & $\mathrm{F}$ & 46 & 1 & $\mathrm{~A}_{3} \mathrm{~A}_{29} \mathrm{~B}_{44} \mathrm{Bw}_{4}$ & lung, liver, soft tissue & $\mathrm{CT}$ \\
\hline 12 G.D. & $M$ & 46 & 0 & $\mathrm{~A}_{3} \mathrm{~A}_{28} \mathrm{~B}_{21} \mathrm{~B}_{35} \mathrm{Cw}_{4}$ & lymph node & NT \\
\hline I3 R.G. & $M$ & 65 & I & $\mathrm{A}_{10} \mathrm{~B}_{8} \mathrm{~B}_{38} \mathrm{Bw}_{4} \mathrm{Bw}_{6} \mathrm{Cw}_{7}$ & lung, soft tissue & BIOCT \\
\hline I4 T.A. & $\mathrm{F}$ & 61 & i & $\mathrm{A}_{2} \mathrm{~A}_{19} \mathrm{~B}_{35} \mathrm{~B}_{37} \mathrm{Bw}_{4} \mathrm{Bw}_{6} \mathrm{Cw}_{4}$ & soft tissue & $\mathrm{CT}+\mathrm{RT}$ \\
\hline I5 B.A. & $\mathrm{F}$ & 59 & 2 & $\mathrm{~A}_{2} \mathrm{~A}_{9} \mathrm{~B}_{39} \mathrm{~B}_{44} \mathrm{Bw}_{4} \mathrm{Bw}_{6} \mathrm{Cw}_{5}$ & liver, soft tissue & BIOCT, locoregional CT \\
\hline 16 C.P. & $\mathrm{F}$ & 39 & 0 & $\mathrm{~A}_{9} \mathrm{~A}_{19} \mathrm{~B}_{14} \mathrm{~B}_{44} \mathrm{Bw}_{4} \mathrm{Bw}_{6} \mathrm{Cw}_{5}$ & kidney, soft tissue & Locoregional CT \\
\hline 17 O.M. & $M$ & 56 & I & $\mathrm{A}_{19} \mathrm{~A}_{28} \mathrm{~B}_{5} \mathrm{~B}_{16} \mathrm{Bw}_{4} \mathrm{Bw}_{6}$ & lung, soft tissue & $\mathrm{BIOCT}$ \\
\hline I8 L.B. & $\mathrm{F}$ & 39 & 2 & & pelvis, lymph node & $\mathrm{BIOCT}$ \\
\hline 19 M.J.L. & $\mathrm{F}$ & 37 & 0 & & $\begin{array}{l}\text { lung, kidney, lymph node, soft } \\
\text { tissue }\end{array}$ & BIOCT \\
\hline 20 O.G. & $M$ & 65 & 2 & $\mathrm{~A}_{23} \mathrm{~A}_{32}$ & $\begin{array}{l}\text { adrenal gland, lymph node, soft } \\
\text { tissue }\end{array}$ & BIOCT \\
\hline \multirow[t]{11}{*}{ 2I M.R. } & $\mathrm{F}$ & 38 & 0 & & lymph node & BIOCT \\
\hline & & & & & 2I Viscera: & $13 \mathrm{BIOCT}$ \\
\hline & & & & & - I spleen & $3 \mathrm{BIO}$ \\
\hline & & & & & - 5 liver & $4 \mathrm{CT}$ \\
\hline & & & & & - 8 lung & 2 Locoregional CT \\
\hline & & & & & - 3 kidney & $2 \mathrm{RT}$ \\
\hline & & & & & - 2 adrenal gland & I NT \\
\hline & & & & & - 2 pelvis & \\
\hline & & & & & 2 Bone & \\
\hline & & & & & 8 Lymph node & \\
\hline & & & & & 9 Soft tissue & \\
\hline
\end{tabular}

PS $(E C O G)=$ performance status according ECOG; $C T=$ chemotherapy; $\mathrm{RT}=$ radiotherapy;

$\mathrm{BIO}=$ Immunotherapy (Interferon, Inteleukin-2); BIOCT= chemotherapy+immunotherapy; NT= no treatment. Male/Female 13/8

Median age 52 years $(35-75)$.

P.S.: $0=8 ; 1=8 ; 2=5$

DC phenotype characteristics are shown in Table 2. iDC and $\mathrm{mDC}$ phenotyping was similar to that described in the literature, and there were no relevant differences in DC obtained from fresh or frozen tissue [4].

DC were pulsed with ATH in 9 cases, with ATH + ATL in 2 patients, and with ATL in 10 patients. During the course of the study we decided to continue using, where possible, only ATL-pulsed DC (ATL should, in theory, have a higher percentage of antigenic protein).

\section{Clinical results}

In the 8 patients treated with iDC, we observed 3 stabilizations (SD), each of 6 months' duration, and 5 PD. Overall survival (OS) of the SD patients was 45, 26 and 7 months, whereas that of the PD patients ranged from 4 to 
Table 2: Surface expression of DC markers in infused DC*

\begin{tabular}{lcc}
\hline Marker & iDC & mDC \\
& Median \% (range) & Median \% (range) \\
\hline CDIA & $15.5(0-58)$ & $7(0-77)$ \\
CDI4 & $0(0-17)$ & $4(0-67)$ \\
CD80 & $0(0-25)$ & $62(2-98)$ \\
CD83 & $0(0-25)$ & $47(2-86)$ \\
CD86 & $30(0-90)$ & $71(5-96)$ \\
HLA-DR & $51.5(3-95)$ & $78(13-100)$ \\
CCR7 & $2.5(0-47) \S$ & $45(1-91)$ \\
\hline
\end{tabular}

iDC, immature dendritic cells; mDC: mature dendritic cells. \$value calculated on $3 / 8$ patients vaccinated with iDC.

*Data represent the percentage of positive cells out of the total number of DC analyzed.

10 months. DTH positivity showed a weak response for both ATH and KLH in the patient with the longest survival (median OS 7.5 months, range 4-45). A weak positivity to only KLH was seen in the patient with a 26-month survival, whereas no response was observed in the remaining patients (Table 3A).

In the $13 \mathrm{mDC}$-treated patients, one complete response (CR) of 8 months' duration ( $\mathrm{OS}=32+$ months), one par- tial response (PR) lasting 3 months ( $\mathrm{OS}=14$ months) and 2 mixed responses (MR) of 12 and 6 months' duration (OS $=28+$ and 22 months, respectively) were obtained. There were also 3 SD lasting 7+, 6 and $3+$ months (the third patient is still undergoing treatment) ( $\mathrm{OS}=7+, 14$ and $3+$ months, respectively) and $6 \mathrm{PD}$ with a median OS of 5.5 months (range 3-20). Median OS was 8 months (range 3-32+).

Patient no. 12 (46-year old man), who had numerous metastatic abdominal and pelvic lymph node localizations, obtained a CR of 8 months, and was the only patient who had not received previous treatment. He developed vitiligo (Figure 1) and the DTH test confirmed a good response to ATL and KLH. Baseline and first-evaluation CT scan images are shown in Figure 2. Patient no. 9 rapidly obtained a PR for lung and lymph node lesions but developed brain metastases after only 3 months. MR was observed in patient nos. 10 and 14, in whom subcutaneous and lymph node metastases disappeared and reappeared for 6 and 12 months, respectively. These patients showed positive DTH for KLH, the former also a strong positive reaction for ATL. All data are analytically reported in Table 3B.

Table 3A: Immunological and clinical response in patients vaccinated with iDC

\begin{tabular}{|c|c|c|c|c|c|c|c|c|c|}
\hline \multirow[t]{2}{*}{ Patient ID } & \multirow[t]{2}{*}{$\begin{array}{c}\text { No. of } \\
\text { Vaccinations }\end{array}$} & \multirow[t]{2}{*}{$\begin{array}{l}\text { Antigens } \\
\text { (Type of } \\
\text { Lysate) }\end{array}$} & \multirow{2}{*}{$\begin{array}{c}\text { Median } \\
\text { No. of } \\
\text { Administe } \\
\text { red Cells } \times \\
10^{6} \text { (range) }\end{array}$} & \multicolumn{2}{|c|}{$\begin{array}{l}\text { DTH Best Response } \\
\text { after } 4 \text { or More } \\
\text { Vaccinations. }\end{array}$} & \multirow[t]{2}{*}{ Vitiligo } & \multirow[t]{2}{*}{$\begin{array}{l}\text { Clinical } \\
\text { Response }\end{array}$} & \multirow[t]{2}{*}{$\begin{array}{l}\text { Response } \\
\text { Duration } \\
\text { (Months) }\end{array}$} & \multirow[t]{2}{*}{$\begin{array}{l}\text { Overall } \\
\text { Survival } \\
\text { (Months) }\end{array}$} \\
\hline & & & & $\mathrm{L} / \mathrm{H}$ & $\mathrm{KLH}$ & & & & \\
\hline I L.A. & 8 & $\mathrm{H}$ & $\begin{array}{c}49.5(15- \\
82)\end{array}$ & + & + & & SD & 6 & 45 \\
\hline 2 G.I. & 5 & L & $\begin{array}{c}13(4.5- \\
26)\end{array}$ & - & + & & SD & 6 & 26 \\
\hline 3 M.G. & 5 & L & $\begin{array}{l}11(7- \\
16.2)\end{array}$ & - & - & $+/-$ & SD & 6 & 7 \\
\hline 4 S.P. & 8 & L & $\begin{array}{c}26.5(10- \\
43.5)\end{array}$ & - & - & & PD & - & 8 \\
\hline 5 G.C. & 6 & L & $\begin{array}{c}19(9.6- \\
32)\end{array}$ & - & - & & PD & - & 10 \\
\hline 6 Z.V. & 5 & $\mathrm{~L} / \mathrm{H}$ & $\begin{array}{l}11.3(6.4- \\
21.5)\end{array}$ & - & - & & PD & - & 4 \\
\hline 7 G.L. & 6 & $\mathrm{H}$ & $\begin{array}{c}22.6(16.4- \\
48)\end{array}$ & - & - & & PD & - & 5 \\
\hline 8 B.A. & 4 & $\mathrm{H}$ & $15(12-51)$ & - & - & & PD & - & 5 \\
\hline $\begin{array}{l}\text { No. of } \\
\text { Patients }\end{array}$ & $\begin{array}{l}\text { Administrati } \\
\text { on Route }\end{array}$ & Site & $\begin{array}{c}\text { No. of } \\
\text { Inoculatio } \\
\text { ns }\end{array}$ & & & & & & \\
\hline $8 \mathrm{iDC}$ & 4 i.d. and 4 s.c. & $\begin{array}{l}6 \text { inguinal and } \\
2 \text { axillary }\end{array}$ & $6-8$ & & & & & & \\
\hline
\end{tabular}

DTH, delayed-type hypersensitivity; L, autologus lysate; $\mathrm{H}$, autologous homogenate; $\mathrm{KLH}$, keyhole limpet hemocyanin; SD, stabilization; PD, progressive disease.

i.d., intradermal; s.c., subcutaneous 
Table 3B: Immunological and clinical response in patients vaccinated with mDC

\begin{tabular}{|c|c|c|c|c|c|c|c|c|c|}
\hline \multirow[t]{2}{*}{ Patient ID } & \multirow[t]{2}{*}{$\begin{array}{c}\text { No. of } \\
\text { Vaccinatio } \\
\text { ns }\end{array}$} & \multirow[t]{2}{*}{$\begin{array}{l}\text { Antigens } \\
\text { (Type of } \\
\text { Lysate) }\end{array}$} & \multirow{2}{*}{$\begin{array}{c}\text { Median } \\
\text { No. of } \\
\text { Administe } \\
\text { red Cells } \times \\
10^{6} \text { (range) }\end{array}$} & \multicolumn{2}{|c|}{$\begin{array}{c}\text { DTH Best Response } \\
\text { after } 4 \text { or More } \\
\text { Vaccinations }\end{array}$} & \multirow[t]{2}{*}{ Vitiligo } & \multirow[t]{2}{*}{$\begin{array}{c}\text { Clinical } \\
\text { Response }\end{array}$} & \multirow[t]{2}{*}{$\begin{array}{l}\text { Response } \\
\text { Duration } \\
\text { (Months) }\end{array}$} & \multirow[t]{2}{*}{$\begin{array}{l}\text { Overall } \\
\text { Survival } \\
\text { (Months) }\end{array}$} \\
\hline & & & & $\mathrm{L} / \mathrm{H}$ & KLH & & & & \\
\hline 9 P.M. & 7 & $\mathrm{~L}$ & $\begin{array}{c}11.4(9- \\
24.1)\end{array}$ & - & - & & PR & 3 & 14 \\
\hline 10 P.M. & 15 & $L$ & $\begin{array}{c}15(2.8- \\
24)\end{array}$ & ++ & ++++ & & MR & 6 & 22 \\
\hline II R.L. & 10 & $\mathrm{H}$ & $\begin{array}{c}9.5(4- \\
13.4)\end{array}$ & - & ++ & & SD & 9 & 14 \\
\hline 12 G.D. & 16 & $\mathrm{~L} / \mathrm{H}$ & $\begin{array}{c}12.6(2.8- \\
20.8)\end{array}$ & ++ & +++ & + & CR & 8 & $32+$ \\
\hline I 3 R.G. & 4 & $\mathrm{H}$ & $9.3(8-26)$ & - & +++ & & PD & - & 8 \\
\hline I4 T.A. & 13 & $\mathrm{H}$ & $9(1.2-12)$ & - & ++ & & MR & 12 & $28+$ \\
\hline I5 B.A. & 4 & $\mathrm{H}$ & $\begin{array}{c}5.9(3.7- \\
12)\end{array}$ & - & - & & PD & - & 7 \\
\hline 16 C.P. & 6 & $\mathrm{H}$ & $\begin{array}{c}7.8(1.6- \\
15)\end{array}$ & - & ++ & & PD & - & 20 \\
\hline 17 O.M. & 4 & $\mathrm{H}$ & $\begin{array}{l}11.5(10- \\
21)\end{array}$ & - & - & & PD & - & 5 \\
\hline I8 L.B. & 4 & $L$ & $\begin{array}{l}12.5(10- \\
15.5)\end{array}$ & - & - & & PD & - & 3 \\
\hline 19 M.J.L. & 8 & $\mathrm{~L}$ & $6(2.2-10)$ & + & +++ & + & SD & $7+$ & $7+$ \\
\hline 20 O.G. & 5 & $L$ & $\begin{array}{c}10(8.8- \\
12.3)\end{array}$ & - & - & & PD & - & 3 \\
\hline 2I M.R. & 4 & $\mathrm{~L}$ & $9.2(8-10)$ & + & ++ & & SD (u.t.) & $3+$ & $3+$ \\
\hline $\begin{array}{l}\text { No. of } \\
\text { Patients }\end{array}$ & $\begin{array}{l}\text { Administr } \\
\text { ation } \\
\text { Route }\end{array}$ & Site & $\begin{array}{c}\text { No. of } \\
\text { Inoculatio } \\
\text { ns }\end{array}$ & & & & & & \\
\hline $13 \mathrm{mDC}$ & 13 i.d. & $\begin{array}{l}10 \text { inguinal } \\
\text { and } 3 \\
\text { axillary }\end{array}$ & $8-10$ & & & & & & \\
\hline
\end{tabular}

DTH, delayed-type hypersensitivity; L, autologous lysate; $H$, autologous homogenate; $K L H$, keyhole limpet hemocyanin.

PD, progressive disease; MR, mixed response; SD, stabilization; PR, partial response; CR, complete response; u.t., undergoing treatment. i.d., intradermal; s.c., subcutaneous

The OR percentage for the 21 patients treated was $19 \%$, which increased to $30.7 \%$ (4/13) when only the results obtained with mDC were considered. The overall percentage of patients who did not progress was $47.6 \%(10 / 21)$, rising to $53.8 \%(7 / 13)$ for those treated with mDC. Our data do not seem to have been influenced by age, sex, or HLA distribution (in 8/10 patients there was a distribution of 2 patients for each of the principle alleles, A1, A2, A3 and A11). There does not appear to be any specific correlation between response and site of disease or type of pretreatment, although it should be remembered that the only patient who obtained a CR had not been pretreated. Futhermore, the number of cells injected would not appear to affect response.
Conversely, initial PS may have exerted an influence on response; all 5 patients with PS $=2$ at baseline progressed. Clinical response obviously correlated positively with OS: 11 patients with progressive disease (PD) had a median OS of 5 months (range 3-20), whereas the 10 who did not progress had a median OS of 21 months (range $3^{+}-45$ ).

\section{Toxicity}

Apart from swelling, redness and pruritus around the site of inoculation, no noteworthy toxicities or side-effects were observed. A low fever with mild flu-like symptoms (grade 1-2) accompanied the administration of IL-2 from the 3rd to the 7th day of treatment. No autoimmune phenomena were observed apart from the onset of vitiligo in 


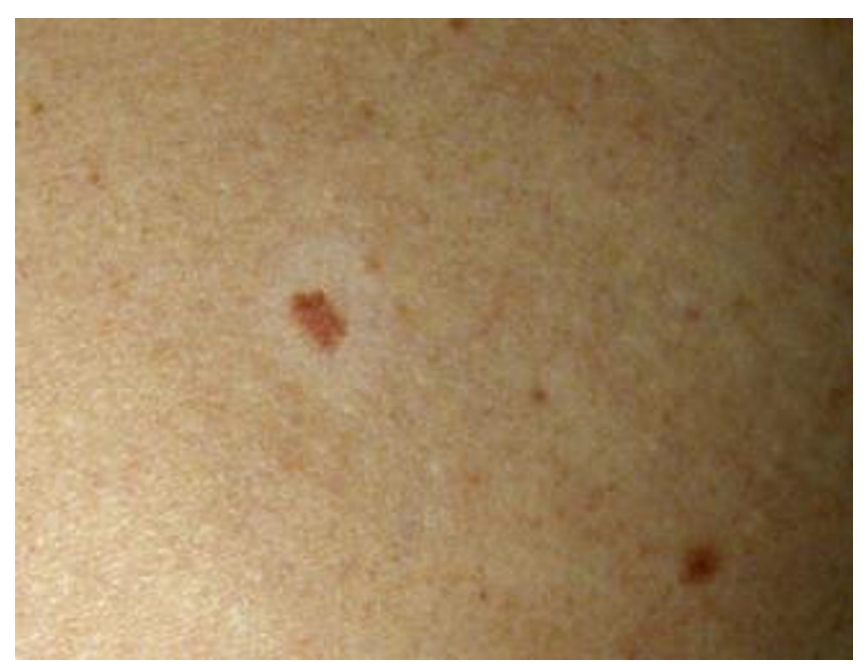

Figure I

Onset of vitiligo in patient no. 12 who had $C R$ after treatment with $\mathrm{mDC}$.

2 patients and the flaring up of a pre-existing vitiligo in a third patient.

\section{In Vivo immunomonitoring}

Amongst the 10 patients with non progressive disease (NPD), only 2 had completely negative DTH reactions for both KLH and ATL/ATH, whereas the 5 patients who developed a response to ATL/ATH were all responders. Correlating this with OS, it can be seen that, amongst patients with a positive DTH reaction (10 patients, 8 of whom had NPD), median survival was 24 months (range $\left.3^{+}-45\right)$, whereas those with negative DTH (11 patients, 2 of whom had NPD), had a median OS of 5 months (range 3-14). The actuarial curve of survival in relation to a pos-
Baseline

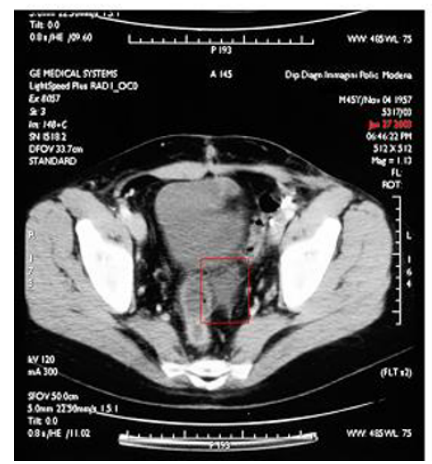

After 4th vaccination

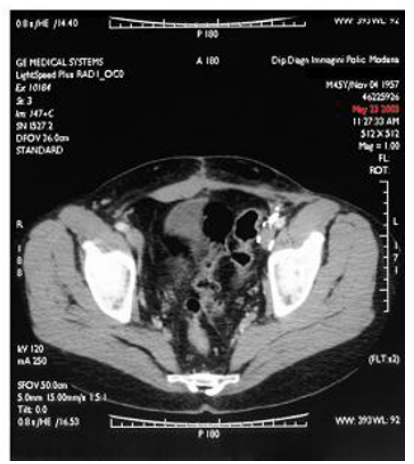

Figure 2

Baseline and post $4^{\text {th }}$ vaccination CT scan of patient no. 12 , treated with $\mathrm{mDC}$. The patient had an 8-month CR of the abdominal soft tissue lesions. itive or negative DTH reaction shows that 24-month OS was $51 \%$ in DTH+ patients compared to $0 \%$ in DTHpatients $(\mathrm{P}<0.001)$ at a median follow-up of 32 months (Figure 3). None of the patients who began treatment with a PS of 2 showed a positive DTH test.

\section{In Vitro immunomonitoring}

In vitro immunomonitoring was performed by evaluating the number of lymphocytes in peripheral blood that are capable of producing gamma-IFN after stimulation with KLH and ATL/ATH. The test was only commercialized recently and was carried out on 10 patients ( 1 treated with iDC and 9 with $\mathrm{mDC}$ ).

Clinical responses in 7 patients corresponded with the indications of the test (70\%): positivity was correlated with NPD in 4 cases and with PD in 3 patients. Comparing the results from the in vitro test with those of DTH stimulation using both KLH and ATL/ATH, overall concordance was 75\% (Table 4).

\section{Discussion}

The practice of antitumor vaccination with DC has brought with it new hope, especially for patients with melanoma, who obtain unsatisfactory results from traditional therapies [30,31]. The high number of known tumor antigens makes melanoma a good target for vaccine therapy [8]. DC vaccination is generally easy to administer and induces low toxicity, but studies published to date are difficult to compare with each other because of the small cases series involved, the limited number of clinical responses observed, and the numerous methodologies of DC preparation used: Cranmer, in fact, recently listed up to 12 possible variations in culture methodology and treatment modalities [32].

Crucial issues such as the best antigens or the most effective evaluation criteria to use have still to be clarified. DC derived from peripheral blood rather than from bone marrow tend to be used and it has been seen that $\mathrm{mDC}$ are undoubtedly better at migrating to regional lymph nodes and are more effective at determining an immunological and clinical response than iDC $[14,33,34]$. It has also recently been reported that intradermal administration results in a higher DC migration than subcutaneous injection $[21,35]$.

However, one of the main problems of vaccination therapy remains the type of antigens to use. Pulsing DC with known single peptides enables us to accurately monitor immunization, but literature results highlight poor, shortterm clinical responses, probably due to tumor escape [36,37]. Whilst pulsing with tumor extracts (lysate, apoptotic bodies, heat shock proteins, etc.) theoretically implies that all tumor antigens are represented, it also 
Fig. 3

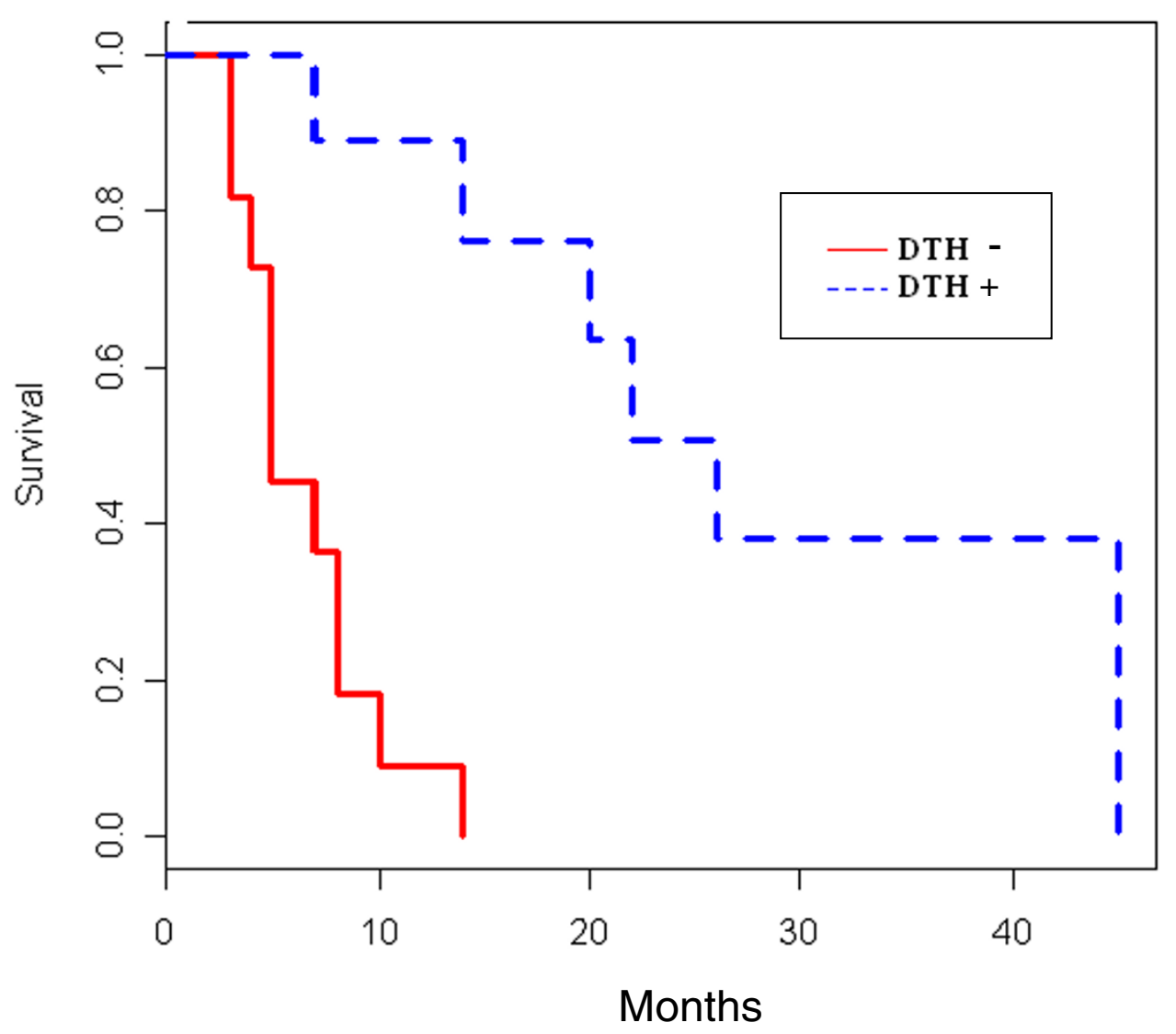

\begin{tabular}{|c|c|c|c|c|c|c|c|}
\hline \multirow{2}{*}{ DTH } & \multirow{2}{*}{ No. of Patients } & \multirow{2}{*}{ Events } & \multirow{2}{*}{$\begin{array}{c}\text { Median OS } \\
\text { (months) }\end{array}$} & \multicolumn{5}{|c|}{ \% OS } \\
\cline { 5 - 8 } & & & & 3 mths & 6 mths & 12 mths & 24 mths \\
\hline- & 11 & 5 & 82 & 46 & 9 & 0 \\
\hline+ & 10 & 6 & 24 & 100 & 100 & 88 & 51 \\
\hline
\end{tabular}

Log-Rank = $15.8(1), P<0.001$

Median follow-up $=32$ months

\section{Figure 3}

Actuarial curves of overall survival (OS) based on DTH results. Eleven patients had negative DTH with a median OS of 5 months and no survival at 24 months. Ten patients had positive DTH (for ATL/ATH and/or for KLH) and a median OS of 24 months, with $50 \%$ still alive after 2 years $(P<0.001)$. 
Table 4: In vitro immunomonitoring (Miltenyi Test): comparison between IFN- $\gamma$ secreting lymphocytes after stimulation with KLH and ATL/ATH, and DTH test and clinical outcome

\begin{tabular}{|c|c|c|c|c|c|c|}
\hline Patient ID & Stimulation & Baseline & $\begin{array}{c}\text { After } 4 / 6 \\
\text { Vaccinations }\end{array}$ & $\begin{array}{c}\text { After } 8 / 13 \\
\text { Vaccinations }\end{array}$ & DTH & $\begin{array}{l}\text { Clinical } \\
\text { Response }\end{array}$ \\
\hline \multirow[t]{2}{*}{4 S.P. ${ }^{a}$} & KLH & 0 & 0 & & Negative & PD \\
\hline & $\mathrm{L}$ & 0 & 0 & & Negative & \\
\hline \multirow[t]{2}{*}{9 P.M.b } & $\mathrm{KLH}$ & & 0 & & Negative & PR \\
\hline & $\mathrm{L}$ & & 0 & & Negative & \\
\hline \multirow{3}{*}{$\begin{array}{l}10 \\
\text { P.M. } \\
\text { MR }\end{array}$} & & $\mathrm{KLH}$ & 0 & 0 & 186 & Positive \\
\hline & & & & & & \\
\hline & L & 0 & 0 & 0 & Positive & \\
\hline \multirow{4}{*}{$\begin{array}{l}\text { I } 2 \\
\text { G.D.b } \\
\text { CR }\end{array}$} & & KLH & 133 & 1238 & 2253 & Positive \\
\hline & & & & & & \\
\hline & & & & & & \\
\hline & $L$ & 56 & 456 & 13405 & Positive & \\
\hline \multirow[t]{2}{*}{ I 4 T.A. ${ }^{\mathrm{b}}$} & KLH & 4 & 356 & 73 & Positive & MR \\
\hline & $\mathrm{H}$ & 0 & 0 & 0 & Negative & \\
\hline \multirow[t]{2}{*}{16 C.P. ${ }^{b}$} & KLH & 0 & 103 & & Positive & PD \\
\hline & $\mathrm{H}$ & 0 & 0 & & Negative & \\
\hline \multirow[t]{2}{*}{ 18 L.B.b } & KLH & 264 & 110 & & Negative & PD \\
\hline & $\mathrm{L}$ & 0 & 0 & & Negative & \\
\hline \multirow{2}{*}{$\begin{array}{l}19 \\
\text { M.J.L.b } \\
\text { SD }\end{array}$} & & $\mathrm{KLH}$ & 0 & 0 & & Positive \\
\hline & L & 0 & 0 & & Positive & \\
\hline \multirow{4}{*}{$\begin{array}{l}20 \\
\text { O.M.b } \\
\text { PD }\end{array}$} & & $\mathrm{KLH}$ & 0 & 0 & & Negative \\
\hline & & & & & & \\
\hline & & & & & & \\
\hline & L & 0 & 0 & & Negative & \\
\hline \multirow{4}{*}{$\begin{array}{l}2 I \\
\text { M.R.b } \\
\text { SD }\end{array}$} & & $\mathrm{KLH}$ & 0 & 99 & & Positive \\
\hline & & & & & & \\
\hline & & & & & & \\
\hline & $\mathrm{L}$ & 0 & 292 & & Positive & \\
\hline
\end{tabular}

DTH, delayed-type hypersensitivity; L, autologous tumor lysate; $\mathrm{H}$, autologous tumor homogenate; $\mathrm{KLH}$, keyhole limpet hemocyanin.

$\mathrm{a}=$ pts treated with iDC.

$\mathrm{b}=$ pts treated with $\mathrm{mDC}$.

bold $=$ data corresponding to test

complicates the process of specific immunomonitoring, requires sizeable quantities of tumor tissue, and results in DC being loaded with a large number of other non antigenic proteins that could reduce, in terms of percentages, the efficacy of the exposure [6,38-41]. Novel methods of pulsing with tumor RNA or with a selection of RNA antigens could perhaps result in increased immune efficacy, especially if we bear in mind the large number of melanoma-restricted genes that have already been identified and codified $[9,42]$.

Clinical evaluation also poses a problem. There is a growing need to modify RECIST criteria, widely used in oncology, when assessing clinical responses in vaccine therapy, e.g. to define mixed responses or responses that occur after an initial progression. Once a vaccine strategy has been clarified or better defined, a modified integrated system of clinical evaluation will be needed [43].
New strategies must also be sought to overcome tumor immunosuppression $[44,45]$. The use of lymphoablative chemotherapy has been hypothesized to reduce or eliminate the component of T-regulator lymphocytes before vaccination [46-49]. Studies in this area could also clarify the still controversial role of IL-2 as a vaccine adjuvant [50-53] and could help to provide valuable information about new molecular targets or cytokines [54,55].

Recent publications would seem to indicate that the presence and/or activation of specific lymphocytes induced by immunostimulation correlates positively with survival [56-59]. Our results concur with this finding and also indicate the need for a better selection of patients, especially in view of the fact that poor PS would seem to correlate with no clinical or immunological response. Patients with minimal residual disease or evidence of probable immunocompetence can be considered candidates for controlled vaccine trials $[60,61]$. 
In conclusion, although vaccination treatment with DC pulsed with KLH and ATL/ATH is an experimental approach and still requires numerous adjustments and verifications, it would seem to be practicable, non toxic, and most importantly, effective in prolonging OS if administered in a subgroup of patients who show immunoreactivity.

\section{Abbreviations}

DC, dendritic cell; OR, overall response; iDC, immature dendritic cell; mDC, mature dendritic cell; ATL, autologous tumor lysate; ATH, autologous tumor homogenate; KLH, keyhole limpet hemocyanin; DTH, delayed-type hypersensitivity; PS, Performance Status; MP, mixed response; PBMC, peripheral blood monocytes; IFN- $\gamma$, interferon-gamma; SD, stabilization; NPD, non-progressive disease.

\section{Competing interests}

The author(s) declare that they have no competing interests.

\section{Authors' contributions}

RR and LR participated in the design of the study and were responsible for the clinical side of the study. AR, MP, LF and $\mathrm{MS}$ also participated in the study design and were responsible for the biological part of the study. GM performed the apheresis collections. $\mathrm{MB}$ performed the mathematical and statistical analysis. All authors read and approved the final manuscript.

\section{Acknowledgements}

The authors wish to thank Gráinne Tierney for editing the manuscript.

This work was partially supported by the Italian Ministry of Health (grant nos. R.F. 2000.352, R.F. 2002.234, R.F.00.184, and R.F. 2003.II6).

\section{References}

I. Banchereau J, Palucka AK, Dhodapkar M, Burkeholder S, Taquet N, Rolland A, Taquet S, Coquery S, Wittkowski KM, Bhardwaj N, Pineiro $L$, Steinman R, Fay J: Immune and clinical responses in patients with metastatic melanoma to CD34(+) progenitor-derived dendritic cell vaccine. Cancer Res 200 I, 6 1:645 I-6458.

2. Ichim CV: Revisiting immunosurveillance and immunostimulation: Implications for cancer immunotherapy. J Transl Med 2005, 3:8.

3. O'Neill DW, Adams S, Bhardwaj N: Manipulating dendritic cell biology for the active immunotherapy of cancer. Blood 2004, 104:2235-2246.

4. Banchereau J, Palucka AK: Dendritic cells as therapeutic vaccines against cancer. Nat Rev Immunol 2005, 5:296-306.

5. Ridgway D: The first $\mathbf{1 0 0 0}$ dendritic cell vaccinees. Cancer Invest 2003, $21: 873-886$.

6. Rosenberg SA, Yang JC, Restifo NP: Cancer immunotherapy: moving beyond current vaccines. Nat Med 2004, 10:909-915.

7. Kaufman HL: Integrating bench with bedside: the role of vaccine therapy in the treatment of solid tumors. J Clin Oncol 2005, 23:659-661.

8. Novellino L, Castelli C, Parmiani G: A listing of human tumor antigens recognized by T cells: March 2004 update. Cancer Immunol Immunother 2005, 54:187-207.
9. Wang E, Panelli MC, Zavaglia K, Mandruzzato S, Hu N, Taylor PR, Seliger B, Zanovello P, Freedman RS, Marincola FM: Melanomarestricted genes. J Transl Med 2004, 2:34.

10. Mackensen A, Herbst B, Chen JL, Kohler G, Noppen C, Herr W, Spagnoli GC, Cerundolo V, Lindemann A: Phase I study in melanoma patients of a vaccine with peptide-pulsed dendritic cells generated in vitro from CD34(+) hematopoietic progenitor cells. Int J Cancer 2000, 86:385-392.

II. Thurner B, Haendle I, Roder C, Dieckmann D, Keikavoussi P, Jonuleit H, Bender A, Maczek C, Schreiner D, von den Driesch P, Brocker EB, Steinman RM, Enk A, Kampgen E, Schuler G: Vaccination with mage-3AI peptide-pulsed mature, monocyte-derived dendritic cells expands specific cytotoxic $T$ cells and induces regression of some metastases in advanced stage IV melanoma. J Exp Med 1999, 190:1669-1678.

12. Schuler-Thurner B, Dieckmann D, Keikavoussi P, Bender A, Maczek C, Jonuleit H, Roder C, Haendle I, Leisgang W, Dunbar R, Cerundolo V, von Den Driesch P, Knop J, Brocker EB, Enk A, Kampgen E, Schuler G: Mage-3 and influenza-matrix peptide-specific cytotoxic $T$ cells are inducible in terminal stage HLA-A2.I+ melanoma patients by mature monocyte-derived dendritic cells. J Immunol 2000, 165:3492-3496.

13. Pardoll D, Allison J: Cancer immunotherapy: breaking the barriers to harvest the crop. Nat Med 2004, 10:887-892.

14. Banchereau J, Steinman RM: Dendritic cells and the control of immunity. Nature 1998, 392:245-252.

15. Schuler G, Schuler-Thurner B, Steinman RM: The use of dendritic cells in cancer immunotherapy. Curr Opin Immunol 2003, I5: I38-1 47.

16. Ridolfi R, Ridolfi L, Petrini M, Fiammenghi L, Riccobon A: Dendritic cell vaccination and immunostimulation in advanced melanoma. Expert Rev Vaccines 2003, 2:825-833.

17. Adams $S$, O'Neill D, Bhardwaj N: Maturation matters: importance of maturation for antitumor immunity of dendritic cell vaccines. J Clin Oncol 2004, 22:3834-3835.

18. Sussman J], Parihar R, Winstead K, Finkelman FD: Prolonged culture of vaccine-primed lymphocytes results in decreased antitumor killing and change in cytokine secretion. Cancer Res 2004, 64:9124-9130.

19. Panelli MC, Wunderlich J, Jeffries J, Wang E, Mixon A, Rosenberg SA, Marincola FM: Phase I study in patients with metastatic melanoma of immunization with dendritic cells presenting epitopes derived from the melanoma-associated antigens MART-I and gp I 00. J Immunother 2000, 23:487-498.

20. Lau R, Wang F, Jeffery G, Marty V, Kuniyoshi J, Bade E, Ryback ME, Weber J: Phase I trial of intravenous peptide-pulsed dendritic cells in patients with metastatic melanoma. J Immunother 200 I, 24:66-78.

21. Ridolfi R, Riccobon A, Galassi R, Giorgetti G, Petrini M, Fiammenghi L, Stefanelli M, Ridolfi L, Moretti A, Migliori G, Fiorentini G: Evaluation of in vivo labelled dendritic cell migration in cancer patients. J Transl Med 2004, 2:27.

22. Shimizu K, Fields RC, Redman BG, Giedlin M, Mule J]: Potentiation of immunologic responsiveness to dendritic cell-based tumor vaccines by recombinant interleukin-2. Cancer J Sci Am 2000, 6(SuppI I):S67-S75.

23. Slingluff $C L$ Jr, Petroni GR, Yamshchikov GV, Hibbitts S, Grosh WW, Chianese-Bullock KA, Bissonette EA, Barnd DL, Deacon DH, Patterson JW, Parekh J, Neese PY, Woodson EM, Wiernasz CJ, Merrill P: Immunologic and clinical outcomes of vaccination with a multiepitope melanoma peptide vaccine plus low-dose interleukin-2 administered either concurrently or on a delayed schedule. J Clin Oncol 2004, 22:4474-4485.

24. Zhang H, Chua KS, Guimond M, Kapoor V, Brown MV, Fleisher TA, Long LM, Bernstein D, Hill BJ, Douek DC, Berzofsky JA, Carter CS, Read EJ, Helman LJ, Mackall CL: Lymphopenia and interleukin-2 therapy alter homeostasis of CD4+CD25+ regulatory $T$ cells. Nat Med 2005, I I:1238-1243.

25. Andersen MH, Gehl J, Reker S, Geertsen P, Becker JC, thor Stratem $P$ : Concomitant administration of interleukin-2 during therapeutic vaccinations against cancer: the good, the bad, or the evil? J Clin Oncol 2005, 23:5265-5267.

26. de la Rosa M, Rutz S, Dorninger H, Scheffold A: Interleukin-2 is essential for CD4+CD25+ regulatory $T$ cell function. Eur J Immunol 2004, 34:2480-2488. 
27. Miller $A B$, Hoogstraten $B$, Staquet $M$, Winkler $A$ : Reporting results of cancer treatment. Cancer 198I, 47:207-2I4.

28. Therasse P, Arbuck SG, Eisenhauer EA, Wanders J, Kaplan RS, Rubinstein L, Verweij J, Van Glabbeke M, van Oosterom AT, Christian MC, Gwyther SG: New guidelines to evaluate the response to treatment in solid tumors. European Organization for Research and Treatment of Cancer, National Cancer Institute of the United States, National Cancer Institute of Canada. J Natl Cancer Inst 2000, 92:205-2I6.

29. Keilholz U, Weber J, Finke JH, Gabrilovich DI, Kast WM, Disis ML, Kirkwood JM, Scheibenbogen C, Schlom J, Maino VC, Lyerly HK, Lee PP, Storkus W, Marincola F, Worobec A, Atkins MB: Immunologic monitoring of cancer vaccine therapy: results of a workshop sponsored by the Society for Biological Therapy. J Immunother 2002, 25:97-138.

30. Atkins MB: The treatment of metastatic melanoma with chemotherapy and biologics. Curr Opin Oncol 1997, 9:205-213.

31. Tsao H, Atkins MB, Sober AJ: Management of cutaneous melanoma. New Engl J Med 2004, 35 I:998-1012.

32. Cranmer LD, Trevor KT, Hersh EM: Clinical applications of dendritic cell vaccination in the treatment of cancer. Cancer Immunol Immunother 2004, 53:275-306.

33. Nestle FO, Alijagic S, Gilliet M, Sun Y, Grabbe S, Dummer R, Burg G, Schadendorf $D$ : Vaccination of melanoma patients with peptide- or tumor lysate-pulsed dendritic cells. Nat Med 1998, 4:328-332.

34. Schuler-Thurner B, Schultz ES, Berger TG, Weinlich G, Ebner S, Woerl P, Bender A, Feuerstein B, Fritsch PO, Romani N, Schuler G: Rapid induction of tumor-specific type I $T$ helper cells in metastatic melanoma patients by vaccination with mature, cryopreserved, peptide-loaded monocyte-derived dendritic cells. J Exp Med 2002, I 95: I 279-I 288.

35. Smithers M, O'Connell K, MacFadyen S, Chambers M, Greenwood K, Boyce A, Abdul-Jabbar I, Barker K, Grimmett K, Walpole E, Thomas $\mathrm{R}$ : Clinical response after intradermal immature dendritic cell vaccination in metastatic melanoma is associated with immune response to particulate antigen. Cancer Immunol Immunother 2003, 52:4I-52.

36. Andersen MH, Keikavoussi P, Brocker EB, Schuler-Thurner B, Jonassen M, Sondergaard I, Straten PT, Becker JC, Kampgen E: Induction of systemic CTL responses in melanoma patients by dendritic cell vaccination: cessation of CTL responses is associated with disease progression. Int J Cancer 200I, 94:820-824.

37. Toungouz M, Libin M, Bulte F, Faid L, Lehmann F, Duriau D, Laporte M, Gangii D, Bruyns C, Lambermont M, Goldman M, Velu T: Transient expansion of peptide-specific lymphocytes producing IFN-gamma after vaccination with dendritic cells pulsed with MAGE peptides in patients with mage-AI/A3-positive tumors. J Leukoc Biol 200I, 69:937-943.

38. Rosenberg SA, Yang JC, Schwartzentruber DJ, Hwu P, Marincola FM, Topalian SL, Restifo NP, Sznol M, Schwarz SL, Spiess PJ, Wunderlich JR, Seipp CA, Einhorn JH, Rogers-Freezer L, White DE: Impact of cytokine administration on the generation of antitumor reactivity in patients with metastatic melanoma receiving a peptide vaccine. J Immunol 1999, I 63:1690-1695.

39. Krause SW, Neumann C, Soruri A, Mayer S, Peters JH, Andreesen R: The treatment of patients with disseminated malignant melanoma by vaccination with autologous cell hybrids of tumor cells and dendritic cells. J Immunother 2002, 25:42 I-428.

40. Chang AE, Redman BG, Whitfield JR, Nickoloff BJ, Braun TM, Lee PP, Geiger JD, Mule J]: A phase I trial of tumor lysate-pulsed dendritic cells in the treatment of advanced cancer. Clin Cancer Res 2002, 8:1021-1032.

4I. O'Rourke MG, Johnson M, Lanagan C, See J, Yang J, Bell JR, Slater GJ, Kerr BM, Crowe B, Purdie DM, Elliott SL, Ellem KA, Schmidt CW: Durable complete clinical responses in a phase I/II trial using an autologous melanoma cell/dendritic cell vaccine. Cancer Immunol Immunother 2003, 52:387-395.

42. Panelli MC, Martin B, Nagorsen D, Wang E, Smith K, Monsurro V, Marincola FM: A genomic- and proteomic-based hypothesis on the eclectic effects of systemic interleukin-2 administration in the context of melanoma-specific immunization. Cells Tissues Organs 2004, I77:124-131.

43. Simon RM, Steinberg SM, Hamilton M, Hildesheim A, Khleif S, Kwak LW, Mackall CL, Schlom J, Topalian SL, Berzofsky JA: Clinical trial designs for the early clinical development of therapeutic cancer vaccines. J Clin Oncol 200 I, I 9: I848-1854.

44. Marincola FM, Jaffee EM, Hicklin DJ, Ferrone S: Escape of human solid tumors from $\mathbf{T}$-cell recognition: molecular mechanisms and functional significance. Adv Immunol 2000, 74: I8I-273.

45. Taylor DD, Gercel-Taylor C, Lyons KS, Stanson J, Whiteside TL: Tcell apoptosis and suppression of $\mathrm{T}$-cell receptor/CD3-zeta by Fas ligand-containing membrane vesicles shed from ovarian tumors. Clin Cancer Res 2003, 9:5 II3-5II9.

46. Dudley ME, Wunderlich JR, Robbins PF, Yang JC, Hwu P, Schwartzentruber DJ, Topalian SL, Sherry R, Restifo NP, Hubicki AM, Robinson MR, Raffeld M, Duray P, Seipp CA, Rogers-Freezer L, Morton KE, Mavroukakis SA, White DE, Rosenberg SA: Cancer regression and autoimmunity in patients after clonal repopulation with antitumor lymphocytes. Science 2002, 298:850-854.

47. Dudley ME, Wunderlich JR, Yang JC, Sherry RM, Topalian SL, Restifo NP, Royal RE, Kammula U, White DE, Mavroukakis SA, Rogers L], Gracia GJ, Jones SA, Mangiameli DP, Pelletier MM, Gea-Banacloche J, Robinson MR, Berman DM, Filie AC, Abati A, Rosenberg SA: Adoptive cell transfer therapy following non-myeloablative but lymphodepleting chemotherapy for the treatment of patients with refractory metastatic melanoma. J Clin Oncol 2005, 23:2346-2357.

48. Ahmadzadeh $M$, Rosenberg SA: IL-2 administration increases CD4+CD25hiFoxp3+ regulatory $T$ cells in cancer patients. Blood 2006, 107:2409-24I4.

49. Powell DJ Jr, Parker LL, Rosenberg SA: Large-scale depletion of CD25+ regulatory $T$ cells from patient leukapheresis samples. J Immunother 2005, 28:403-4II.

50. Slingluff $C L ~ J r$, Speiser DE: Progress and controversies in developing cancer vaccines. J Transl Med 2005, 3:18.

51. Fontenot JD, Rasmussen JP, Gavin MA, Rudensky AY: A function for interleukin 2 in Foxp3-expressing regulatory $\mathbf{T}$ cells. Nat Immunol 2005, 6: I|42-||5|.

52. Antony PA, Restifo NP: CD4+CD25+ T regulatory cells, immunotherapy of cancer, and interleukin-2. J Immunother 2005, 28:120-128.

53. Malek TR, Bayer AL: Tolerance, not immunity, crucially depends on IL-2. Nat Rev Immunol 2004, 4:665-674.

54. Dranoff G: CTLA-4 blockade: unveiling immune regulation. J Clin Oncol 2005, 23:662-664.

55. Melchionda F, Fry TJ, Milliron MJ, McKirdy MA, Tagaya Y, Mackall CL: Adjuvant IL-7 or IL-I 5 overcomes immunodominance and improves survival of the CD8+ memory cell pool. J Clin Invest 2005, II 5: II77-118.

56. Prasad SJ, Farrand KJ, Matthews SA, Chang JH, McHugh RS, Ronchese $\mathrm{F}$ : Dendritic cells loaded with stressed tumor cells elicit longlasting protective tumor immunity in mice depleted of CD4+CD25+ regulatory T cells. J Immunol 2005, I 74:90-98.

57. Robbins PF, Dudley ME, Wunderlich J, El-Gamil M, Li YF, Zhou J, Huang J, Powell DJ Jr, Rosenberg SA: Cutting edge: persistence of transferred lymphocyte clonotypes correlates with cancer regression in patients receiving cell transfer therapy. J Immunol 2004, I 73:7125-7I30.

58. de Vries IJ, Bernsen MR, Lesterhuis WJ, Scharenborg NM, Strijk SP, Gerritsen MJ, Ruiter DJ, Figdor CG, Punt C], Adema G]: Immunomonitoring tumor-specific $T$ cells in delayed-type hypersensitivity skin biopsies after dendritic cell vaccination correlates with clinical outcome. I Clin Oncol 2005, 23:5779-5787.

59. Escobar A, Lopez M, Serrano A, Ramirez M, Perez C, Aguirre A Gonzalez R, Alfaro J, Larrondo M, Fodor M, Ferrada C, SalazarOnfray F: Dendritic cell immunizations alone or combined with low doses of interleukin-2 induce specific immune responses in melanoma patients. Clin Exp Immunol 2005, I 42:555-668.

60. Stift A, Friedl J, Dubsky P, Bachleitner-Hofmann T, Schueller G, Zontsich T, Benkoe T, Radelbauer K, Brostjan C, Jakesz R, Gnant M: Dendritic cell-based vaccination in solid cancer. J Clin Oncol 2003, 2 I : |35-| 42.

6I. Berd D, Sato T, Maguire HC Jr, Kairys J, Mastrangelo MJ: Immunopharmacologic analysis of an autologous, hapten-modified human melanoma vaccine. J Clin Oncol 2004, 22:403-4I 5. 